\title{
The FAD fishery in the Gulf of Thailand: time for management measures
}

\author{
Pavarot NoranARTTRAGOON ${ }^{1, a}$, Piyachok SinANAN ${ }^{2}$, Nantachai BoONJOHN $^{3}$, Pakjuta KHEMAKORN ${ }^{4}$ \\ and Amararatne YAKUPITIYAGE ${ }^{1}$ \\ 1 Asian Institute of Technology, PO Box 4, Klong Luang, 12120 Pathum Thani, Thailand \\ 2 Eastern Marine Fisheries Research and Development Center (Rayong), 2 Phe, Muang, 21160 Rayong, Thailand \\ 3 Chumphon Marine Fisheries Research and Development Center, 408 Paknam, Muang, 86120 Chumphon, Thailand \\ ${ }^{4}$ Southern Marine Fisheries Research and Development Center (Songkhla), 79/1 Wichianchom Rd., Bo-yang, Muang, \\ 90000 Songkhla, Thailand
}

Received 3 May 2012; Accepted 9 January 2013

\begin{abstract}
Fish aggregating devices (FADs) used in the Gulf of Thailand are made of bamboo poles, twisted wire and coconut leaves, fastened to a concrete block. Purse seines with $2.5 \mathrm{~cm}$ mesh size are used to surround the fish, using fishing boats ranging from 18 to $26 \mathrm{~m}$ in overall length. Fishing grounds are located in the central Gulf of Thailand at a depth of 25-60 m. Catch per unit effort (CPUE), species composition and size of economically important species were analyzed by collecting data from fishing boats using FADs at nine main fishing ports along the Gulf of Thailand between January and December 2007. The results show that the average CPUE was $3351 \mathrm{~kg} \mathrm{day}^{-1}$, which was composed of $88 \%$ pelagic fishes, $5 \%$ demersal fishes, $4 \%$ trash fishes and $2 \%$ squids and cuttlefishes. The major pelagic species were Indian mackerel (Rastrelliger kanagurta), Indian scad (Decapterus russelli) and bigeye scad (Selar crumenophthalmus), which made up 25\%,24\% and $8 \%$ of the total catch, respectively, while neritic tunas (kawakawa; Euthynnus affinis, frigate tuna; Auxis thazard thazard and longtail tuna; Thunnus tonggol) made up 8\% of the total catch. The mean length of ten economically important species was smaller than their size at first maturity, while two species were above their size at first maturity. The results indicated that juvenile fish were mostly being caught by FAD fishery, and this may lead to depletion in fisheries resources and economic loss. Although there is a set of measures to control the use of purse seines, effective management of the FAD capacity is also urgently needed.
\end{abstract}

Keywords: Fish aggregating devices / Purse seine fishery / Pelagic fish / Fisheries resources / Fisheries management / Gulf of Thailand

\section{Introduction}

The coastal waters of Southeast Asia are the most productive and biologically diverse in the world (Pomeroy et al. 2007). Situated in this area, Thailand has one of the world's ten largest fishing industries and the fifth largest in Asia (DOF 2008). The Gulf of Thailand extends northwest from the southern part of the South China Sea and contributes approximately $70 \%$ of the country's total marine catch, with the Andaman Sea coast accounting for the remainder. In 2007, the country's total recorded marine catch was 2.1 million tons, of which 1.5 million tons were from the Gulf of Thailand and 0.6 million tons from the Andaman Sea. In the Gulf of Thailand, pelagic fish represented $58 \%$ of the total landings, worth 8.5 billion Baht (270 million USD) or $63 \%$ of the total

a Corresponding author: pavarot_n@yahoo.com landings value (DOF 2010). Therefore, pelagic fishes are the most important group in terms of both catch and value.

Initially, pelagic species in the Gulf of Thailand were mainly caught in inshore waters, using non-mechanized boats and traditional fishing gears. The most important fishing gear was stationary fishing gear, i.e., a bamboo stake trap. In 1925, the Chinese purse seine or two-boat purse seine was introduced for the short mackerel fishery in the Gulf of Thailand. This consisted of one large sailing boat and two rowing boats. The net was made of cotton yarn treated with liquid from mangrove bark. Although this kind of purse seine has been known to Thai fishers for over 80 years, it has not changed much during this time, except that the cotton net has been replaced by a nylon one. This old-fashioned gear still remains in use, but only on the Andaman Sea off Thailand.

With the appearance of nylon netting material in Thailand in 1954, the old indigenous purse seine underwent major modifications. The net was made of black, and later green, nylon. 


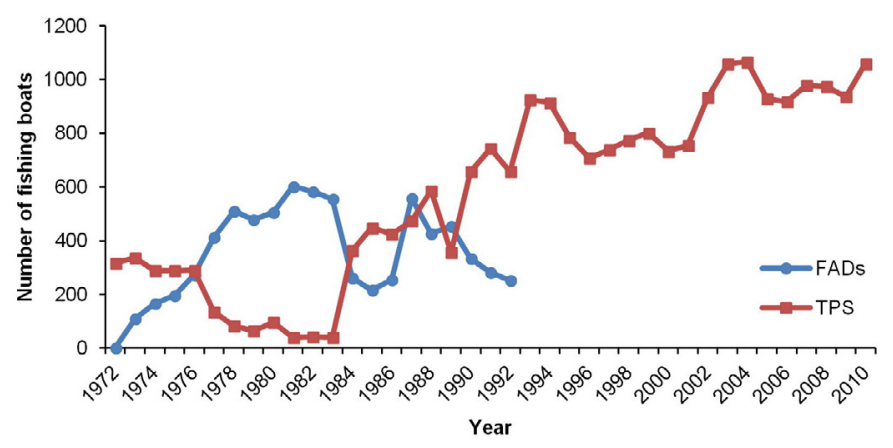

Fig. 1. Number of purse seine fishing boats in the Gulf of Thailand, 1972-2010.

Since 1956, it has been possible to distinguish the so-called Thai purse seine ${ }^{1}$ (TPS) or black purse seine, which uses a mesh size of $2.5 \mathrm{~cm}$ and whose main catch is also short mackerel. By this method, fishing operations are conducted from a single boat, the fish school is found with the naked eye, and the net is hauled by hand on both sides of the boat. In the 1960s, the pelagic fisheries grew swiftly and the TPS increased in relation to the number and size of the fishing vessels. The variety of the species composition in the catch increased, causing fish processing industries to expand steadily, e.g., the canned fish industry.

In 1972, fish aggregating devices (FADs, Thai: "Sung”) were introduced; however, the nets were not modified. TPS was still used to catch either free-swimming fish or fish swarming around FADs. The FAD fishery (Thai: "Uan Lom Sung") was then used in combination with kerosene and butane lamps in order to increase the fish-catching efficiency. Subsequently, in 1979, these lamps were electrified using on board electric generators. In 1977, other important developments occurred in the Thai fishing fleets. The fishing accessory devices, such as sonar, echo sounder and power block (a mechanized pulley used to haul in the nets), were introduced to facilitate fishing. In addition, the fishing boats were enlarged in order to expand the fishing range and number of fishing days. However, the pelagic catch in the Gulf of Thailand rapidly reached a maximum sustainable yield (MSY) of 624318 tons (based on 1971-1995 data; Kongprom et al. 2003). The total pelagic fish landings in the Gulf of Thailand exceeded the MSY in 1992, when 700149 tons was landed, and ranged from 590920 to 695880 tons over the next 12 years. After 2004, the landings constantly decreased and were 551765 tons in 2007 (DOF 2009). Over 30 years, the FAD fishery has been greatly developed for pelagic fisheries, and fishing boats are large vessels with modern equipment on board.

As the result of the introduction of FADs, the number of fishing boats registered for FAD fishing in the Gulf of Thailand increased from one boat in 1972 up to 602 boats in 1981 (Fig. 1). At the same time, the fishers changed their fishing method from catching free-swimming fish to using FADs, due to the abundant pelagic resources in the central Gulf of Thailand and the high attraction efficiency of FADs. Consequently, the number of fishing boats registered for TPS

1 Thai purse seine is used to name both the net and fishing method without using FADs during the fishing operation. continuously decreased in the period 1972-1983. However, in 1984, the situation was reversed. Due to the rapid expansion of the canned tuna industry in 1983, the fishers placed an emphasis on catching neritic tunas (kawakawa, longtail tuna and frigate tuna) using sonar (Supongpan and Saikliang 1987). Therefore, the number of FAD fishing boats decreased severely while TPS fishing boats sharply increased. In fact, TPS can be used to catch pelagic fish with or without FADs. Because there was confusion among fishers about the registration of fishing gear as either TPS or FADs, the purse seine fishing boats have been combined with the TPS since 1993. Thus, only the net is registered, regardless of the fishing method. After that, the number fluctuated but the tendency showed a steady increase. The most recently recorded number of TPS fishing boats was 1059 in 2010 (DOF 2012).

Since FADs are a high efficiency luring method, the state of exploitation of some important pelagic species in the Gulf of Thailand was reported: Indian mackerel was depleted, torpedo scad, goldstripe sardinella and longtail tuna were overexploited, and bigeye scad was fully exploited (Saikliang 1997). The aim of this study was to explore the current state of the FAD fishery in the Gulf of Thailand, including fishing grounds, catch per unit effort (CPUE), species composition, and the length of some economically important species.

\section{FAD characteristics and fishing methods}

FADs in the Gulf of Thailand are made of 3-5 bamboo poles, used as a buoy, and twisted wire and coconut leaves; this structure is fastened to the sea floor with a concrete block (Fig. 2). Fifteen to twenty coconut leaves are tied to the wire from the top down to 20-30 m depth. The space between each coconut leaf is about $2 \mathrm{~m}$. FADs are anchored for a number of days and used in conjunction with TPS. The TPS net is $400-900 \mathrm{~m}$ in length and set at $80-110 \mathrm{~m}$ in depth. The main net is made of black nylon with a $25 \mathrm{~mm}$ mesh size. The fishing boat is $18-26 \mathrm{~m}$ in overall length with a crew of $20-35$ on board. Besides a main fishing boat, there usually is an additional boat (or boats) used (1) as a patrol boat for monitoring FADs in case they are stolen or destroyed by other fishing gears and (2) as an electrical generator boat (a boat equipped with electrical generator and luring light).

Fishing is usually carried out at night, but sometimes during the day. For night-time fishing, a number of FADs are randomly selected to detect fish schools by sonar. If there are moderate numbers of fish found around selected FADs, the electrical generator boat is then used to attract fish schools until enough are detected. Then, the FADs are speedily dragged away and left far from the immediate area. At this point, the fish remain swarming around the electrical generator boat.

For daytime fishing, fish schools are also detected by sonar. If only a small amount of fish is found swarming around a FAD, then this FAD is slowly be towed to a second FAD but quickly dragged away as it passes. The fish will move from the first FAD to the second. Sonar detection is then done once again to detect the fish schools. These steps may be repeated in cases when not many fish are detected. Then a skiff with a luring FAD constructed from 10-15 coconut leaves tied to polyethylene with a $5-\mathrm{kg}$ weight, is floated to the main FAD. 


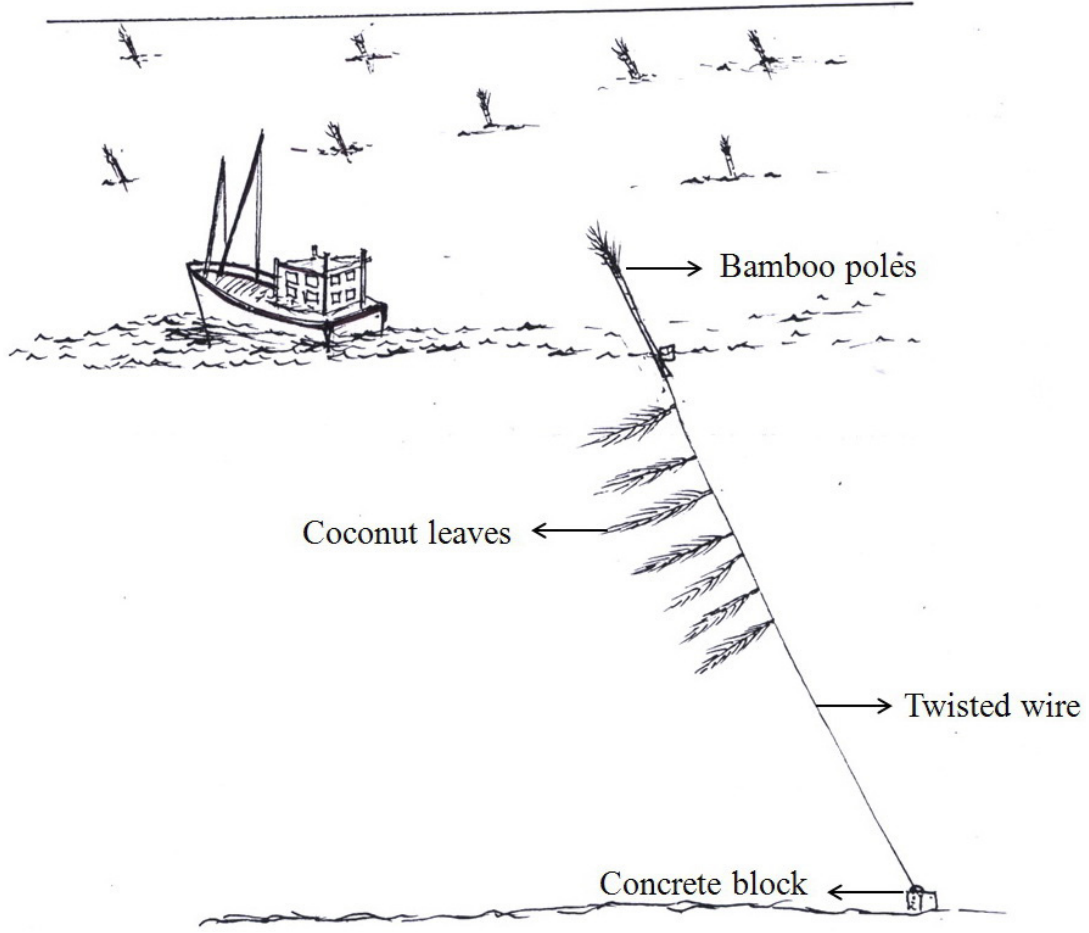

Fig. 2. Construction of fish aggregating devices used in the Gulf of Thailand.

At this point, the luring FAD is released beside the main FAD, which is later dragged off at speed. The fish schools remain swarming around the luring FAD.

When enough fish have been gathered, either by the electrical generator boat or luring FAD, the purse seine is released and the boat encircles the schools at maximum speed. When the fish are inside the net, its end is closed and the bottom is in front of pursed. Once the encirclement is finished, the net is hurriedly hauled aboard using a hydraulic power block attached to a side of the boat. At the same time, the electrical generator boat or skiff sails out of the encircled net and the luring FAD, if used, is hauled away. During hauling, the net is smoothly stacked on the opposite side of the boat in order to be ready for the next fishing operation.

When most of the net has been retrieved, the fish schools are grouped within a restricted area. They are then harvested using a scoopnet and kept on ice in storage rooms without sorting. In the case of high-value species such as neritic tunas or larger-sized fish, which are among the most frequently caught, these fish will be kept in the 200-litre plastic buckets with sea water and ice in the storage rooms in order to keep the fish as fresh as possible. The duration of this operation obviously depends upon the quantity of fish in the net. The number of fishing days per trip is mostly from three to ten days, depending upon the quantity of fish caught, with one to five hauling per day, but usually three hauling per day. The fish are sorted by species/group and size at fishing ports.

\section{Materials and methods}

The study sites were nine fishing ports in six provinces along the Gulf of Thailand, which were divided into 4 zones
(Fig. 3). The sampling areas were as follows: Eastern Gulf of Thailand: Trat and Rayong province; Inner Gulf of Thailand: Samut Prakan province; Western Gulf of Thailand: Chumphon province; Southern Gulf of Thailand: Nakhon Si Thammarat and Songkhla province.

\subsection{Sampling methods}

The data were collected monthly in 2007 from landings of FAD fishing boats. The number of sampled fishing boats per month could not be decided in advance as this depended upon the weather and fishery situations during the survey period, which were set before going to collect the data. If a fisher catches only a small amount of fish, and the estimated catch value is less than the costs of fishing, then no fish is landed and the captain keeps the boat at sea for more days to continue fishing. On the other hand, if the weather is not good, the captain does not take the boat out to fish. However, in the present study, the data were collected from every boat that landed fish where possible.

The 40-50 kg fish per storeroom was sampled in order to identify the species caught, which was done based on Carpenter and Niem (1998, 1999a,b, 2001a,b), and to measure the weight $(\mathrm{g})$ and length $(0.5 \mathrm{~cm}$ class interval). Twelve of the most economically important species were selected to evaluate the state of the fisheries resources caught by the FAD fishery. A hundred of each species from the sampled catch were measured for length and weight. All of the fish above the sample size of 100 were weighed without their length being measured. If the sample did not exceed 100 fish, then the length and weight of all the sampled fish were measured. The 


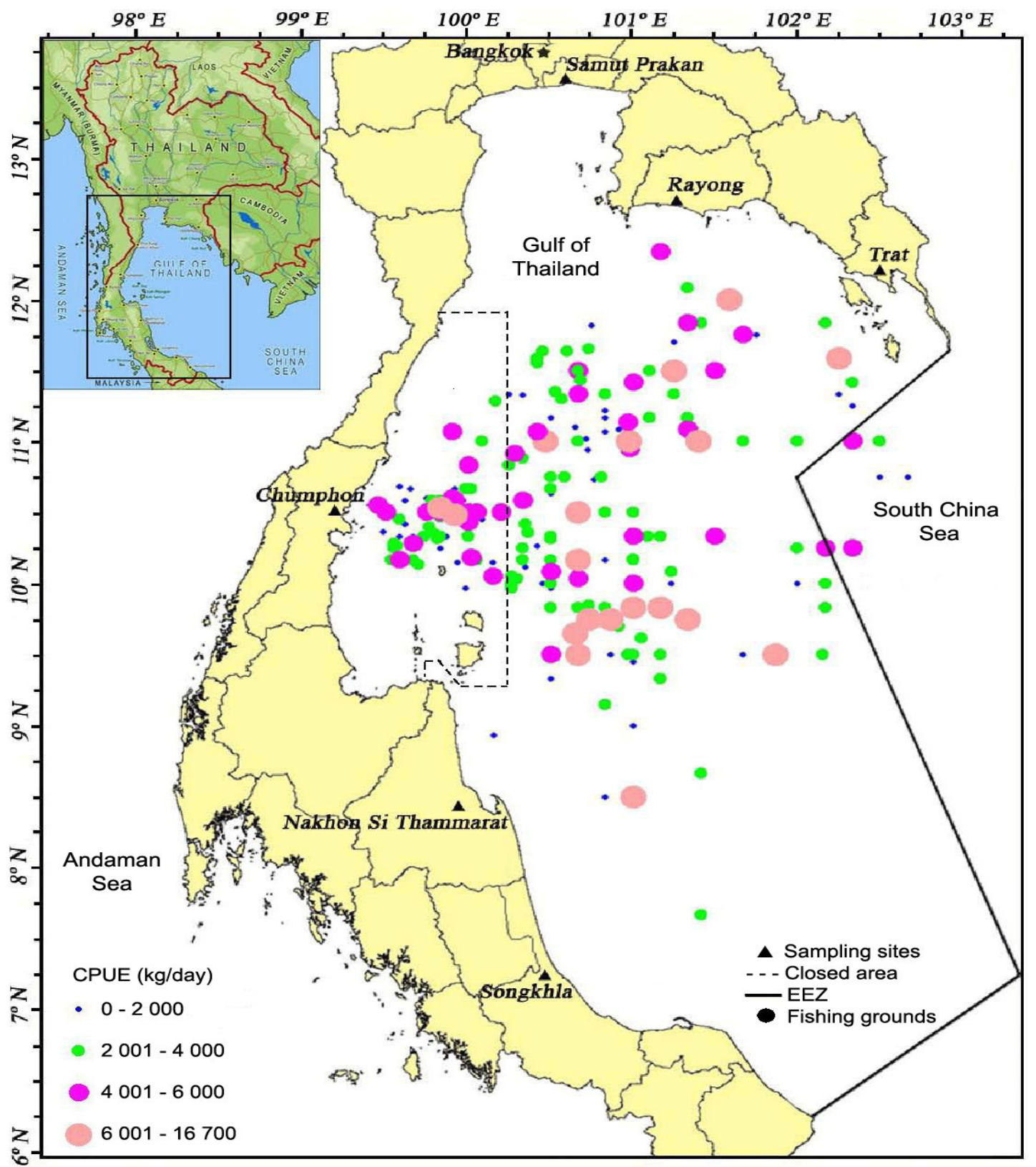

Fig. 3. Sampling sites, fishing grounds and CPUE $\left(\mathrm{kg} \mathrm{day}^{-1}\right)$ of the FAD fishery in the Gulf of Thailand.

captain of the fishing boat, assistant captain, and/or the boat owner were interviewed and the following information obtained: fishery information, i.e., fishing effort, fishing ground, total weight of catch, etc.; and fishing gear characteristics, i.e., mesh size, length and depth of net etc.

\subsection{Data analysis}

The species composition (\%) was analyzed as follows.

Species composition $=\frac{\text { Catch of each species }(\mathrm{kg})}{\text { Total } \text { catch }(\mathrm{kg})} \times 100$
The catch per unit effort of each species (CPUE; $\mathrm{kg} \mathrm{day}^{-1}$ ) and average CPUE were analysed as follows.

$$
\begin{aligned}
& \text { CPUE }=\frac{\text { Catch of each species }(\mathrm{kg})}{\text { Fishing effort }(\text { day })} \\
& \overline{\mathrm{CPUE}}=\frac{\sum_{i=1}^{n} \mathrm{CPUE}_{i}}{n}
\end{aligned}
$$

where $\overline{\mathrm{CPUE}}$ is average CPUE $\left(\mathrm{kg} \mathrm{day}^{-1}\right), \mathrm{CPUE}_{i}$ is CPUE of fishing boat $i$ and $n$ is the total number of fishing boats sampled.

Mean, maximum and minimum length and standard deviations $(\mathrm{cm})$ were analyzed from the length composition of each 
Table 1. Species composition and CPUE of the FAD fishery in the Gulf of Thailand.

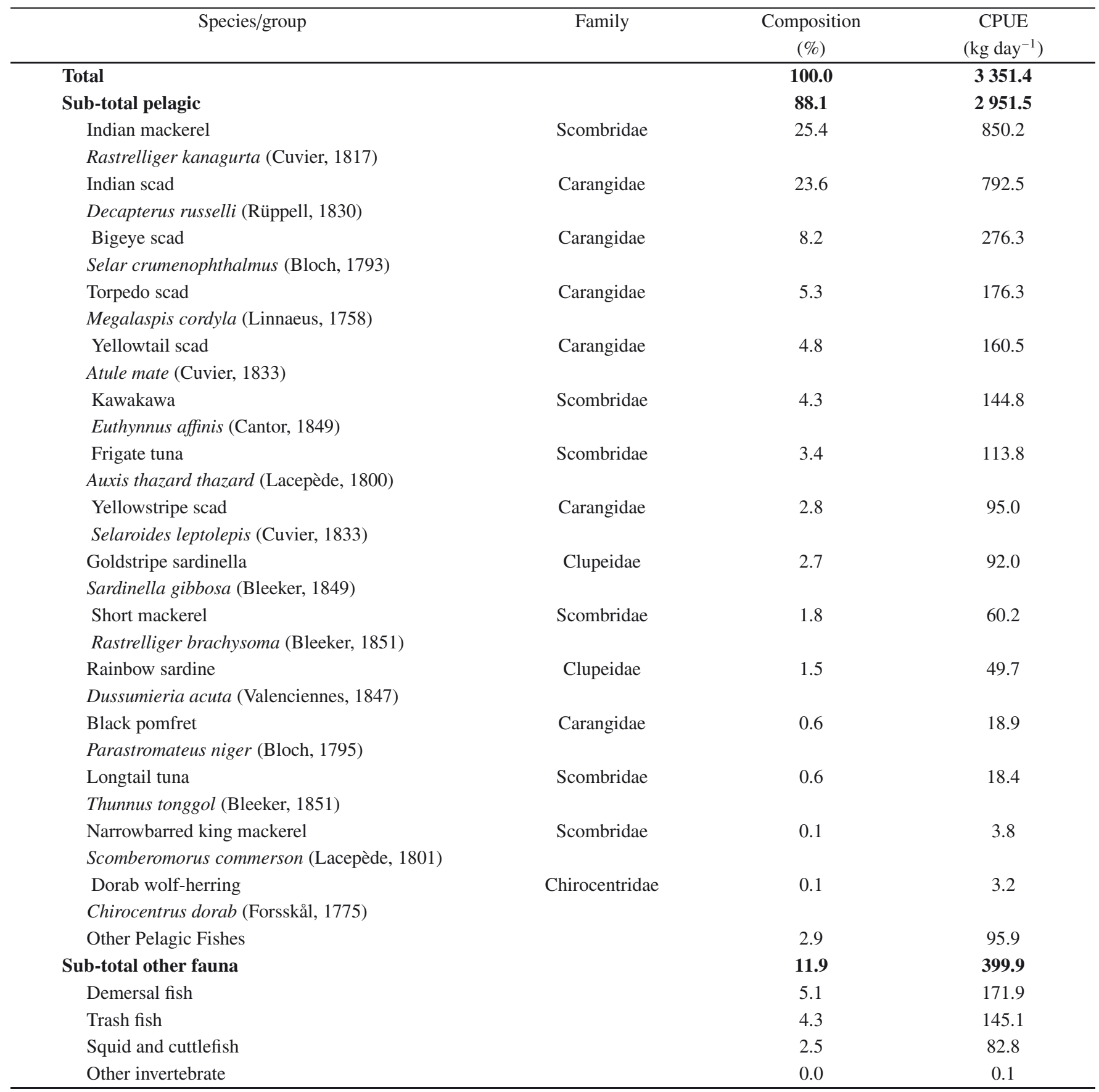

species as follows.

$$
\bar{x}=\frac{\sum_{i=1}^{n} x_{i} f_{i}}{\sum_{i=1}^{n} f_{i}}
$$

where $\bar{x}$ is mean length, $x_{i}$ is mid class interval $i, f_{i}$ is frequency of class interval $i$ and $n$ is the number of class intervals.

\section{Results}

The FAD fishing grounds of this study were located in the central Gulf of Thailand at a depth of 25-60 m (Fig. 3).

\subsection{CPUE and species composition}

The average CPUE of the FAD fishery in the Gulf of Thailand in 2007 was $3351 \mathrm{~kg} \mathrm{day}^{-1}$ (Table 1).

\section{Pelagic fish}

Pelagic fishes were the target group of this FAD fishery and represented $88 \%$ of the total catch, with a CPUE of $2952 \mathrm{~kg} \mathrm{day}{ }^{-1}$. Indian mackerel made up the largest 
Table 2. Size (TL, *except) of economically important species caught by the FAD fishery in the Gulf of Thailand.

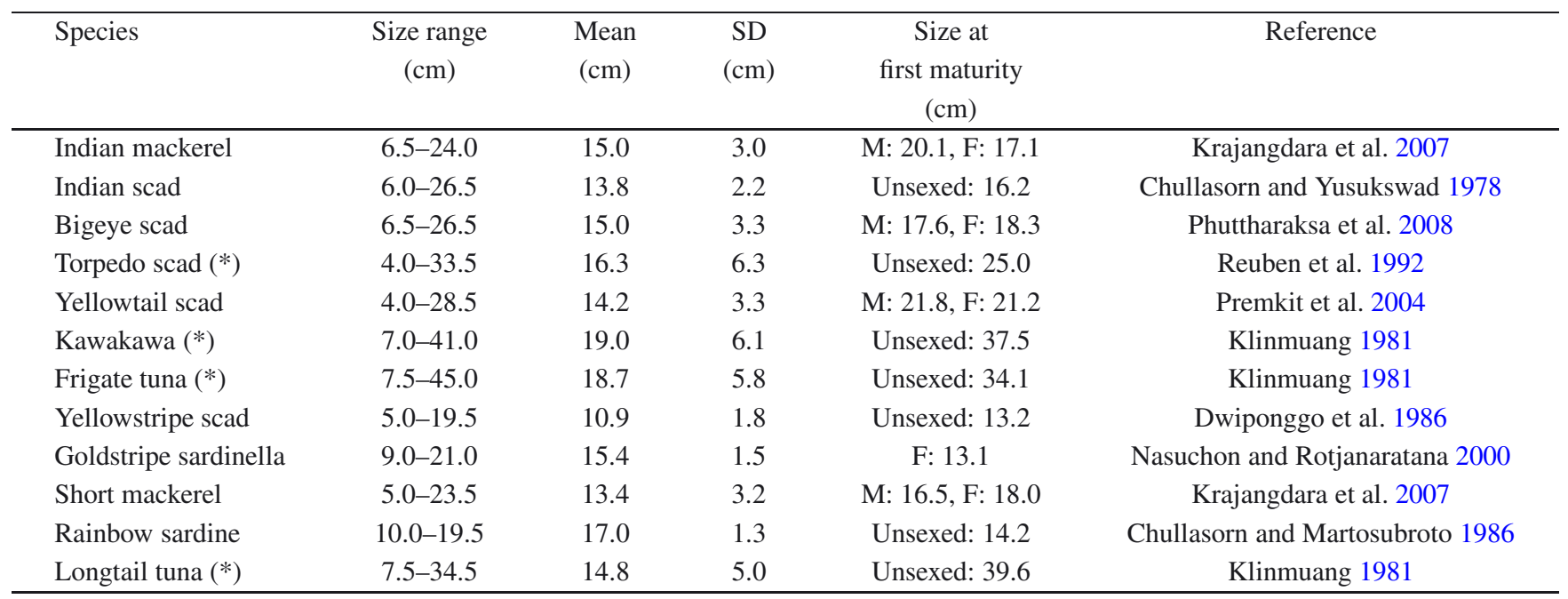

(*) Fork length; $\mathrm{M}$ is male and $\mathrm{F}$ is female.

fraction, at $25 \%$ of the total catch, followed by Indian scad, bigeye scad and torpedo scad, representing $24 \%, 8 \%$ and $5 \%$ of the total catch, respectively; CPUE of these top four species was $850,793,276$ and $176 \mathrm{~kg} \mathrm{day}^{-1}$, respectively.

However, considering the top 15 species groups, Carangids accounted for the greatest part of the catch, followed by Scombrids and Clupeids: $45 \%, 36 \%$ and $4 \%$ of the total catch, respectively. Neritic tunas (kawakawa, frigate tuna and longtail tuna) made up $8 \%$ of the total catch, with a CPUE of $277 \mathrm{~kg} \mathrm{day}^{-1}$. Anchovies, billfishes, dolphin fishes and other pelagic species were rarely caught by the FAD fishery and were grouped as "other pelagic fishes".

\section{Other fauna}

Other fauna were also caught by the FAD fishery, representing $12 \%$ of the total catch and a CPUE of $400 \mathrm{~kg} \mathrm{day}^{-1}$. They were composed of four groups, as follows.

- Demersal fishes made up 5\% of the total catch with a CPUE of $172 \mathrm{~kg} \mathrm{day}^{-1}$. Hairtails, lizardfishes, purplespotted bigeye and snappers represented half of this demersal catch $(51 \%)$.

- Trash fishes consist of small fish even when the species are adult (true trash fish). Much of this part of the catch is sold as fish meal or for poultry feed processing. Trash fishes made up $4 \%$ of the total catch with a CPUE of $145 \mathrm{~kg} \mathrm{day}^{-1}$. Pony fishes, flying fishes and cardinal fishes were the main components of trash fish.

- Squids and cuttlefishes made up 3\% of the total catch with a CPUE of $83 \mathrm{~kg} \mathrm{day}^{-1}$. Squids were found most frequently, while cuttlefishes and octopuses were rarely found in this group.

- Other invertebrates made up less than $0.01 \%$ of the total catch and the CPUE was $0.1 \mathrm{~kg} \mathrm{day}^{-1}$. Shrimps, crabs and shells were included in this group.

\subsection{Size of economically important species}

To evaluate the state of the pelagic fish species caught by the FAD fishery, the mean length of 12 economically important species was analyzed and compared with size at first maturity reported in available technical papers (Table 2). Results showed that the mean lengths of 10 pelagic species caught (Indian mackerel, Indian scad, bigeye scad, torpedo scad, yellowtail scad, kawakawa, frigate tuna, yellowstripe scad, short mackerel and longtail tuna) were smaller than species size at first maturity, while the mean lengths of two sardine species (goldstripe sardinella and rainbow sardine) were larger than species size at first maturity. The length of the main species composition was illustrated as follows.

- Indian mackerel. The length of Indian mackerel was found to be from 6.5 to $24.0 \mathrm{~cm}$, while the mean length was $15.0 \pm 3.0 \mathrm{~cm}$. The reported female size at first maturity was $17.1 \mathrm{~cm}$ (Krajangdara et al. 2007). Over threequarters of the Indian mackerel caught were smaller than the species size at first maturity (Fig. 4a).

- Indian scad. The length of Indian scad was found to be from 6.0 to $26.5 \mathrm{~cm}$, while the mean length was $13.8 \pm 2.2 \mathrm{~cm}$. The reported size at first maturity was $16.2 \mathrm{~cm}$ (Chullasorn and Yusukswad 1978). Almost $90 \%$ of the Indian scad caught were smaller than the species size at first maturity (Fig. 4b).

- Bigeye scad. The length of bigeye scad was found to be from 6.5 to $26.5 \mathrm{~cm}$, while the mean length was $15.0 \pm 3.3 \mathrm{~cm}$. The reported female size at first maturity was $18.3 \mathrm{~cm}$ (Phuttharaksa et al. 2008). Over $80 \%$ of bigeye scad caught were smaller than the species size at first maturity (Fig. 4c).

Previous recordings of the size at first maturity of economically important species were used to classify length distribution into smaller and larger. As a result, the catch of 10 species showed that a high percentage of fishes were smaller than size at first maturity. In addition, most of the yellowtail scad, 

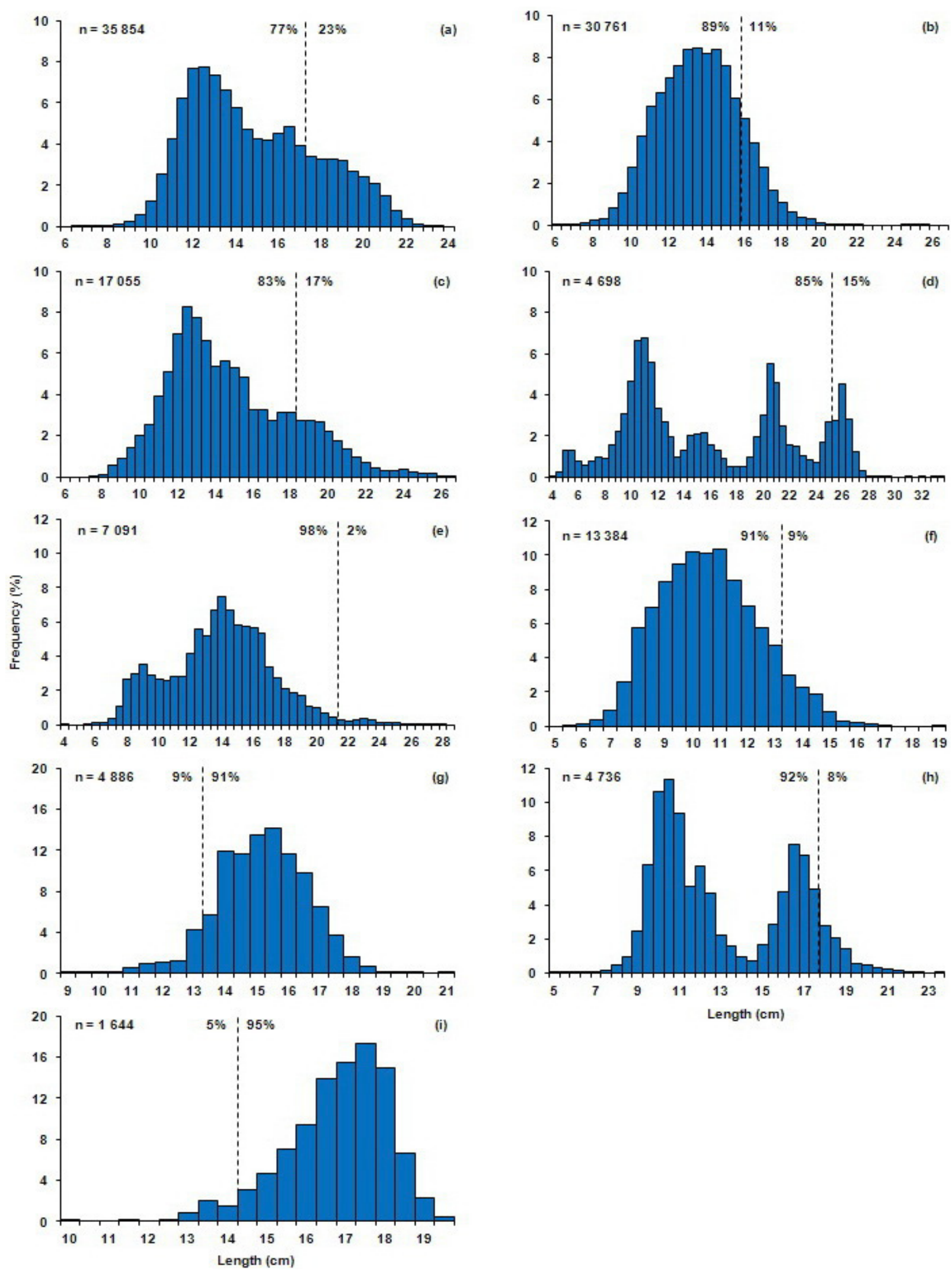

Fig. 4. Length distributions of mackerels, scads and sardines caught by FAD fishery in the Gulf of Thailand: (a) Indian mackerel, (b) Indian scad, (c) bigeye scad, (d) torpedo scad, (e) yellowtail scad, (f) yellowstripe scad, (g) goldstripe sardinella, (h) short mackerel and (i) rainbow sardine. Total length was measured on all these species except torpedo scad, where fork length was measured. Dotted lines show size at first maturity. 
Table 3. Comparison of species composition and CPUE of the FAD fishery in the Gulf of Thailand.

\begin{tabular}{lccc}
\hline \multirow{2}{*}{ Species/group } & \multicolumn{3}{c}{ Composition (\%) } \\
\cline { 2 - 4 } & $1976^{1}$ & $1986^{2}$ & 2007 \\
\hline Sub-total pelagic fish & $\mathbf{9 8 . 7}$ & $\mathbf{9 4 . 1}$ & $\mathbf{8 8 . 1}$ \\
Indian scad & 48.9 & 23.4 & 23.6 \\
Bigeye scad & 19.0 & 12.6 & 8.2 \\
Goldstripe sardinella & 8.6 & 3.1 & 2.7 \\
Indian mackerel & 8.3 & 29.5 & 25.4 \\
Short mackerel & 5.7 & 0.5 & 1.8 \\
Yellowtail scad & 6.8 & 11.4 & 4.8 \\
Yellowstripe scad & 0.7 & 2.5 & 2.8 \\
Neritic tunas & - & 7.5 & 8.3 \\
Other pelagic fish & 0.7 & 3.6 & 10.5 \\
Other & $\mathbf{1 . 3}$ & $\mathbf{5 . 9}$ & $\mathbf{1 1 . 9}$ \\
Average CPUE $\left(\mathrm{kg} \mathrm{day}^{-1}\right)$ & - & 3120.6 & 3351.4 \\
\hline
\end{tabular}

Notes: ${ }^{1}$ Noopetch $1983 ;{ }^{2}$ Noopetch 1987.

yellowstripe scad and short mackerel caught were not sexually mature, representing $98 \%, 91 \%$ and $92 \%$ of the individuals of these species in the catch, respectively (Figs. 4e,f,h). The neritic tuna catch also showed a critically high percentage of small-sized fish: $98 \%$ of kawakawa and 100\% of frigate tuna and longtail tuna caught by FAD fishery were immature (Figs. 5a-c). Only goldstripe sardinella and rainbow sardine showed a high percentage of large-sized individuals (Figs. 4g,i).

\section{Discussion}

Although the average CPUE in 2007 was slightly more than in 1986, the species composition was extremely different from the early stage of FAD development (Table 3). In 1972, the first year that FADs were introduced, the total catch of Indian scad in the Gulf of Thailand was 1920 tons (DOF 1974). The catch increased to 12690 tons in the next year and was highest in 1977, at 126136 tons (DOF 1975, 1979). These figures indicate that the central Gulf of Thailand is the fishing ground for Indian scad and FADs are an effective luring method for catching them. After this peak, the catch continuously decreased, and has been only 45000-70000 tons over the last 10 years (DOF 2000-2010). However, its maximum sustainable yield (MSY), based on 1971-1994 catch and effort data, was 49000 tons (Chullasorn 1998). Therefore, the recorded landings of Indian scad have exceeded the MSY.

CPUE was reported to be similar during two periods: in 1986 , at $3121 \mathrm{~kg} \mathrm{day}^{-1}$, and in 2007 , at $3351 \mathrm{~kg} \mathrm{day}^{-1}$ (Table 3). High CPUE could however be maintained over 20 years due to the expansion of the fishing ground. Formerly, the fishing ground was at a depth of 50-70 $\mathrm{m}$ in the central Gulf of Thailand. Due to increasing fuel prices, the fishing ground was shifted closer to the shore, where depths were 25-60 m (Fig. 2). Although a wide area in the central Gulf has been used for the FAD fishery, the fishing ground can be displaced if catches decline. Modernized fishing technology also keeps the CPUE high. For night-time fishing, for example, higher electrical power and an increased number of bulbs in lighted luring boats attract fish schools more effectively.

As shown in Table 3, when a species represent an increasing percentage of the catch over time, this does not necessarily mean that there was a higher catch. In 2007, for instance, the percentage of Indian mackerel was higher than in 1976, but the cause was that the catch of Indian scad or other species decreased while the catch of Indian mackerel and other species remained stable. Consequently, the percentage of Indian mackerel was higher. Nevertheless, when fisheries resource integrity is maintained, the species composition should not change very much over time (Supongpan 2001).

A few years after FADs were introduced into Thailand, fishing boats were equipped with modern accessories to facilitate fishing and their engines were modified to increase their capacity. As a consequence, neritic tunas, which are excellent swimmers (Dickson 1995) and in strong demand from the canned tuna industry, made up a large percentage of the catch in 1986 and have been caught constantly (Table 3).

The length of some pelagic fishes was compared between this study and previous reports, revealing that the mean length of all selected species in the present study was smaller than in past records (Table 4). However, the mode of length distribution of goldstripe sardinella in this study was larger than the previous reports. This can be explained by the fact that larger sardinella inhabit deeper waters, mostly 20-50 m depth, while smaller ones inhabit shallower waters, mostly 5-20 $\mathrm{m}$ in depth (Chullasorn 1979). Because the FAD fishing grounds were deeper than $25 \mathrm{~m}$, it is not surprising that sardinella length was mostly found to be larger than the reference recorded length, which was based on samples collected from shallow waters. Additionally, the minimum and maximum length of selected species was mostly smaller than previous reports, except the minimum length of goldstripe sardinella and the maximum length of short mackerel.

Despite the fact that decreases in the trophic level of landings are assumed to reflect changes in the fish communities (Goñi 1998; Pauly et al. 2000; Pauly et al. 2001; Cury et al. 2005; Bhathal and Pauly 2008), changes in size structure of species are a strong and more universal indicator of fishing effects (Jennings et al. 2002). The size of the main species caught has changed compared with past recordings (Table 4). Therefore, it can be assumed that the stocks of most pelagic resources caught by the FAD fishery are now being depleted.

This not only leads to resource depletion, but to the catching of juvenile fish, which also causes an economic loss. Noranarttragoon (2007) revealed that the FAD fishery in the Gulf of Thailand made a loss of 10.7 million Baht boat ${ }^{-1}$ year $^{-1}$ (335 thousands USD boat ${ }^{-1}$ year $^{-1}$ ). Based on the estimated number of current FAD fishing boats, the economic loss would be 2700 million Baht year ${ }^{-1}$ (84 million USD year ${ }^{-1}$ ). This means, if the catching of juvenile fishes is avoided and delayed so as to catch them after the size at first maturity has been reached, then new recruitment will be increased, fishers will get more returns, and pelagic resources will be made sustainable in the long term.

Several papers have described the use of indicators in fisheries management (Ali et al. 2005; Jennings 2005; 

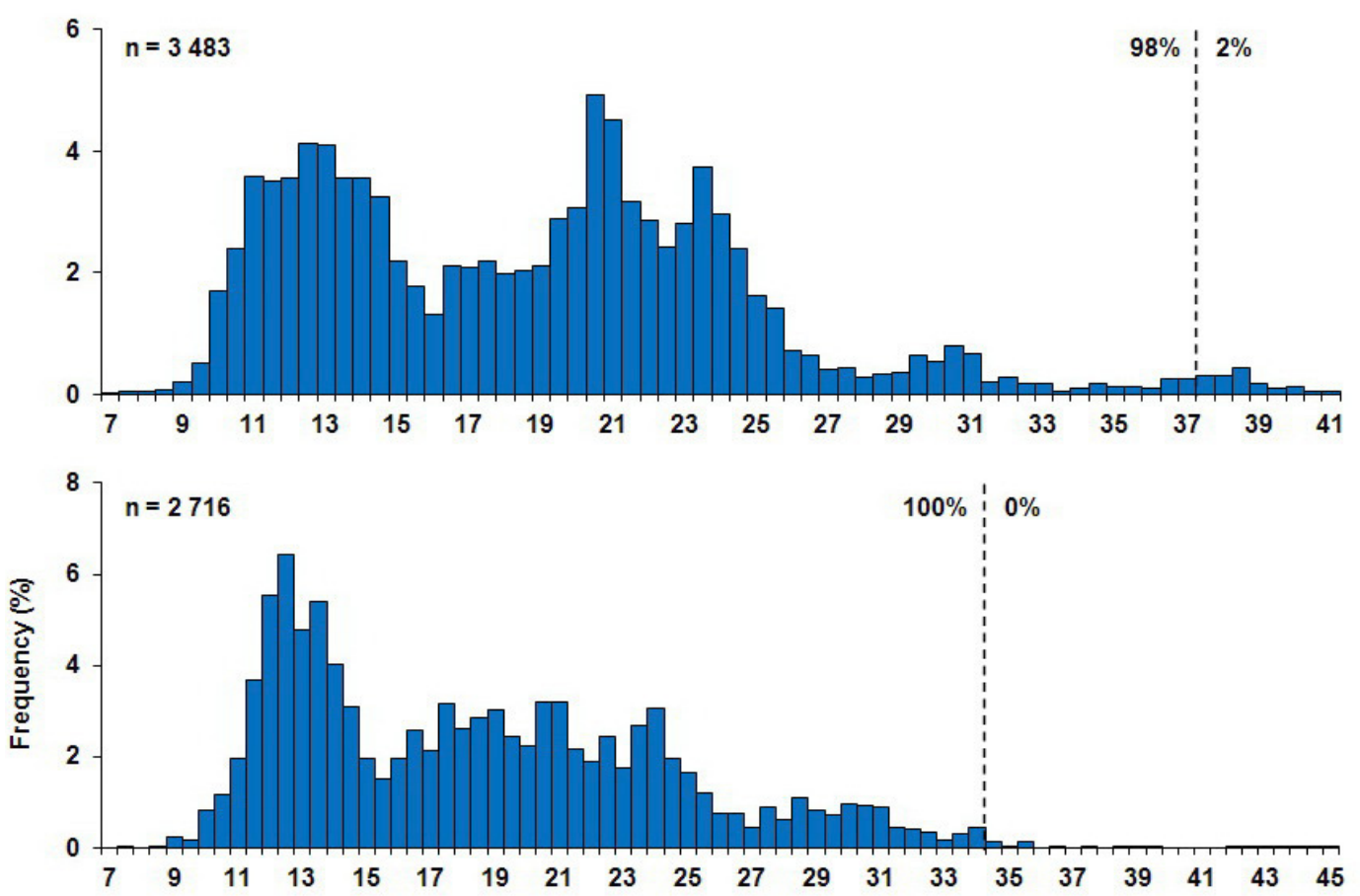

(b)

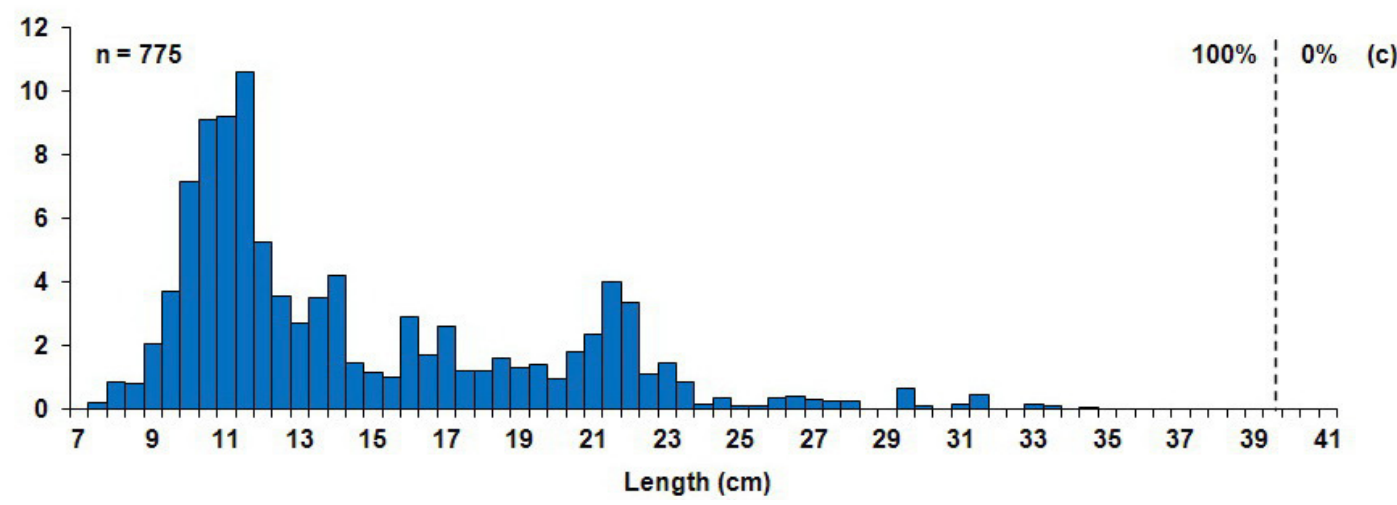

Fig. 5. Length distributions of neritic tunas caught by the FAD fishery in the Gulf of Thailand: (a) kawakawa, (b) frigate tuna and (c) longtail tuna. Fork length was measured on all these species. Dotted lines show size at first maturity.

Raakjær et al. 2007; Piet et al. 2010). Resource indicators are potential indicators to track sustainability (Supongpan 2001). In the present study, some changes in resource status were revealed, including species and length composition. Consequently, possible fisheries management measures should be urgently planned.

Today, the Fisheries Act of 1947 is used to manage the fisheries in Thailand. Although it has been disseminated over 60 years, authorized persons have the right to issue any regulation that will serve the current fisheries situation. Regarding the purse seine, there is a ministerial regulation to determine the net mesh size. Issued on 14 November 1991, no person can use a surrounding net of which the mesh sizes are smaller than $2.5 \mathrm{~cm}$ for fishing at night. Thus, the TPS mesh size currently used is $2.5 \mathrm{~cm}$, and this can be used both day and night. However, there is no regulation to determine the use of FADs, such as the number of FADs and their fishing grounds. As a result, FAD fishery access is presently very open for Thai fishers.
Another regulation regarding the fishing area, which has been in vigour since 1984, is that no commercial fishing gears, including TPS, are allowed in the locality of Prachuap Khiri Khan, Chumphon and Surat Thani (Central-West Gulf of Thailand) between 15 February and 15 May of each year (Fig. 2). Nevertheless, most of the FAD fishing grounds are outside this closed area and the closure time is only 3 months. Therefore, the FAD fishery is not really affected by this closed area regulation.

Although several management plans based on scientific advice have been proposed relating to the FAD fishery (Nootmorn 1989; Jutagate 1997; Chullasorn 1998) and the overall fishing efforts in the Gulf of Thailand (Kongprom et al. 2003; Stobutzki et al. 2006a,b), there has been no further action to control TPS or the FAD fishery. One difficulty in the management of the FAD fishery is that the exact number of FAD fishing boats is unknown because only the net (TPS) is registered. As mentioned earlier, TPS can be used alone or in conjunction with FADs. In some seasons, when fish schools 
Table 4. Length comparison of some pelagic fishes caught by the FAD fishery in the Gulf of Thailand between this study and previous reports.

\begin{tabular}{|c|c|c|c|c|c|c|c|}
\hline \multirow{2}{*}{ Species } & \multicolumn{2}{|c|}{ Mean length $(\mathrm{cm})$} & \multicolumn{2}{|c|}{ Minimum length $(\mathrm{cm})$} & \multicolumn{2}{|c|}{ Maximum length $(\mathrm{cm})$} & \multirow{2}{*}{ Reference } \\
\hline & $\begin{array}{c}\text { This } \\
\text { study }\end{array}$ & $\begin{array}{c}\text { Previous } \\
\text { study }\end{array}$ & $\begin{array}{l}\text { This } \\
\text { study }\end{array}$ & $\begin{array}{c}\text { Previous } \\
\text { study }\end{array}$ & $\begin{array}{l}\text { This } \\
\text { study }\end{array}$ & $\begin{array}{c}\text { Previous } \\
\text { study }\end{array}$ & \\
\hline $\begin{array}{l}\text { Indian mackerel } \\
(1987-1994)^{1}\end{array}$ & 15.0 & 16.5 & 6.5 & 7.0 & 24.0 & 26.0 & Jutagate 1997 \\
\hline $\begin{array}{l}\text { Indian scad } \\
(1975-1981)\end{array}$ & 13.8 & 15.7 & 6.0 & 7.5 & 26.5 & 29.5 & Nootmorn 1989 \\
\hline $\begin{array}{l}\text { Torpedo scad } \\
(1982-1983)\end{array}$ & 16.3 & 23.5 & 4.0 & 11.0 & 33.5 & 37.5 & $\begin{array}{c}\text { Supongpan } \\
\text { and Saikliang } 1987\end{array}$ \\
\hline $\begin{array}{l}\text { Yellowtail scad } \\
(1982-1983)\end{array}$ & 14.2 & 21.6 & 4.0 & 12.0 & 28.5 & 28.5 & $\begin{array}{c}\text { Supongpan } \\
\text { and Saikliang } 1987\end{array}$ \\
\hline $\begin{array}{l}\text { Kawakawa } \\
(1979 / 1984)\end{array}$ & 19.0 & $38.7 / 29.3$ & 7.0 & $18.0 / 15.0$ & 41.0 & $56.0 / 49.0$ & Cheunpan 1985 \\
\hline $\begin{array}{l}\text { Frigate tuna } \\
(1979 / 1984)\end{array}$ & 18.7 & $35.9 / 28.9$ & 7.5 & $19.0 / 15.0$ & 45.0 & $49.0 / 53.0$ & Cheunpan 1985 \\
\hline $\begin{array}{l}\text { Yellowstripe scad } \\
\text { (1980) }\end{array}$ & 10.9 & 12.5 & 5.0 & 5.5 & 19.5 & 17.0 & Noopetch 1984 \\
\hline $\begin{array}{l}\text { Goldstripe sardinella } \\
\text { (1994-1998) }\end{array}$ & $15.5^{2}$ & $12.5^{2}$ & 9.0 & 3.0 & 21.0 & 23.0 & Saikliang 2003 \\
\hline $\begin{array}{l}\text { Short mackerel } \\
(2003-2005)\end{array}$ & 13.4 & $\begin{array}{c}M=17.5 \\
F=17.7\end{array}$ & 5.0 & 11.1 & 23.5 & 23.3 & Krajangdara et al. 2007 \\
\hline $\begin{array}{l}\text { Longtail tuna } \\
(1979 / 1984)\end{array}$ & 14.8 & $40.7 / 38.5$ & 7.5 & $20.0 / 17.0$ & 34.5 & $55.0 / 50.0$ & Cheunpan 1985 \\
\hline
\end{tabular}

Notes: ${ }^{1}$ Year in parentheses is sample collection period; ${ }^{2}$ Length occurring most frequently (mode).

are rarely found, e.g., waxing moon, the fishers will use FADs. On the other hand, although the fishers generally fish on FAD fishing grounds, free-swimming fish can also be caught if they happen to be found by chance during the voyages to and from the fishing port.

Fortunately, there are many opportunities for changes in FAD fishery management. Both input and output controls may be applied to manage the FAD fishery. For example, the number of fishing licenses issued can be limited based on scientific assessments. Other potential management plans include: a reduction of fleet capacity by removing fishing boats through a buyback scheme or overseas fishery extension, limiting the size of the net, controlling the luring light intensity or restricting the fishing periods or areas. It would also be possible to make regulations limiting the number of FADs used per boat or area. For output control, the total amount of fish may be limited through individual transferable quota (ITQ) or total allowable catch (TAC) schemes. However, ecological, economic and social sustainability need to be integral parts of a catch sharing system (Sumaila 2010). On the other hand, catch limitations of a specific species or size of fish landed seem to be difficult due to the multispecies nature of Thailand's fishery.

\section{Conclusion}

The FAD fishery in the Gulf of Thailand has been developing continuously since 1972 and has developed greatly over the last 30 years. The rapid development and expansion of this
FAD fishery has resulted in considerable fishing pressure on the pelagic fish resources in the Gulf of Thailand.

Several indications of possible problems of the FAD fishery in the Gulf of Thailand have been discussed in this paper. Changes in the percentage of species composition, decline in the mean size of the main species caught, and the huge number of juvenile fishes caught are all signs that management actions are needed in the FAD fishery and unregulated open access fishery in the Gulf of Thailand. There is a danger that too many fish are being caught by the FAD fishery before they can spawn and replace themselves, and this may lead to recruitment overfishing. The present situation of unsustainable harvesting of pelagic fishes is bound to continue unless adequate management measures are implemented effectively through a regime of monitoring, control and surveillance. Without the formulation and implementation of approaches to control the use of FADs, it is unlikely that Thailand can be an important producer of captured fisheries products.

\section{References}

Ali R., Ibrahim J., Nuruddin A.A., Muda M.S. (eds.), 2005, Report of the core group meetingon the identification of indicators for sustainable development and management of capture fisheries in the ASEAN region. SEAFDEC-MERDMD, Kuala Terengganu.

Bhathal B., Pauly D., 2008, Fishing down marine food webs' and spatial expansion of coastalfisheries in India, 1950-2000. Fish. Res. 91, 26-34. 
Carpenter K.E., Niem V.H. (eds.), 1998, FAO Species Identification Guide for Fishery Purposes. The living marine resources of the Western Central Pacific. Cephalopods, crustaceans, holothurians and sharks. Rome, FAO, Vol. 2, pp. 687-1396.

Carpenter K.E., Niem V.H. (eds.), 1999a, FAO Species Identification Guide for Fishery Purposes. The living marine resources of the Western Central Pacific. Batoid fishes, chiamaeras and bony fishes part 1 (Elopidae to Linophrynidae). Rome, FAO, Vol. 3, pp. 1397-2068.

Carpenter K.E., Niem V.H. (eds.), 1999b, FAO Species Identification Guide for Fishery Purposes. The living marine resources of the Western Central Pacific. Bony fishes part 2 (Mugilidae to Carangidae). Rome, FAO, Vol 4, pp. 2069-2790.

Carpenter K.E., Niem V.H. (eds.), 2001a, FAO Species Identification Guide for Fishery Purposes. The living marine resources of the Western Central Pacific. Bony fishes part 3 (Menidae to Pomacentridae). Rome, FAO, Vol 5, pp. 2791-3380.

Carpenter K.E., Niem V.H. (eds.), 2001b, FAO Species Identification Guide for Fishery Purposes. The living marine resources of the Western Central Pacific. Bony fishes part 4 (Labridae to Latimeriidae), estuarine crocodiles, sea turtles, sea snakes and marine mammals. Rome, FAO, Vol. 6, pp. 3381-4218.

Cheunpan A., 1985, Present status of tuna resources fishery in the Gulf of Thailand. Department of Fisheries Annual Seminar 1985. 16-18 September 1985. Bangkok, Marine Fisheries Division (MFD), Department of Fisheries (DOF).

Chullasorn S., Martosubroto P., 1986, Distribution and important biological features of coastal fish resources in Southeast Asia. FAO Fisheries Technical Paper 278, Rome, FAO.

Chullasorn S., Yusukswad S., 1978, Preliminary report on the fisheries biology of the round scad (Decapterus spp.) in the Gulf of Thailand. Pelagic Fisheries Report no. 2/1978. Bangkok, MFD, DOF.

Chullasorn S., 1979, Sardines. In: Results of the Seminar on Marine Fisheries Development Program, Annex 4-6. Bangkok, Marine Fisheries Division, DOF.

Chullasorn S., 1998, Status of pelagic fisheries and resources in the Gulf of Thailand. Technical Paper no. 1/1998. Bangkok, MFD, DOF.

Cury P.M., Shannon L.J., Roux J-P., Daskalov G.M., Jerre A., Moloney C.L., Pauly D., 2005, Trophodynamic indicators for an ecosystem approach to fisheries. ICES J. Mar. Sci. 62, 430-442.

Dickson K.A., 1995, Unique adaptations of the metabolic biochemistry of tunas and billfishes for life in the pelagic environment. Environ. Biol. Fish. 42, 65-97.

DOF, 1974, The marine fisheries statistics 1972 base on the sample survey. Bangkok, Fisheries Economics and Planning Sub Division, DOF.

DOF, 1975, The marine fisheries statistics 1973 base on the sample survey. Bangkok, Fisheries Economics and Planning Sub Division, DOF.

DOF, 1979, The marine fisheries statistics 1977 base on the sample survey. Bangkok, Fisheries Economics and Planning Sub Division, DOF

DOF, 2000-2010, The marine fisheries statistics 1998-2007 base on the sample survey. Bangkok, Information Technology Center (ITC), DOF.

DOF, 2008, Fisheries statistics of Thailand 2006. Bangkok, ITC, DOF.

DOF, 2009, Fisheries statistics of Thailand 2007. Bangkok, ITC, DOF.

DOF, 2010, Fisheries statistics of Thailand 2008. Bangkok, ITC, DOF.
DOF, 2012, Thai fishing vessels statistics 2010. Bangkok, ITC, DOF. Dwiponggo A., Hariata T., Banon S., Palomares M.L., Pauly, D., 1986, Growth, mortality and recruitment of commercially important fishes and Penaeid shrimps in Indonesian Waters. ICLARM Technical Reports 17. Jakarta, Research Institute for Marine Fisheries and Manila, International Center for Living Aquatic Resources Management.

Goñi R., 1998, Ecosystem effects of marine fisheries: an overview. Ocean Coast. Manage. 40, 37-64.

Jennings S., Greenstreet S.P.R., Hill L., Piet G.J., Pinnegar J.K., Warr K.J., 2002, Long-term trends in the trophic structure of the North Sea fish community: evidence from stable-isotope analysis, sizespectra and community metrics. Mar. Biol. 141, 1085-1097.

Jennings S., 2005, Indicators to support an ecosystem approach to fisheries. Fish Fish. 6, 212-232.

Jutagate T., 1997, A study on population dynamics of Indian mackerel (Rastrelligerkanagurta Cuvier, 1816) in the Gulf of Thailand during 1987-1993. Master thesis (Fisheries Science). Bangkok, Kasetsart University.

Klinmuang H., 1981, Studies on the size frequency distribution and length/weight relationship of the tunas in the Gulf of Thailand. Technical Paper no. 24. Bangkok, MFD, DOF.

Kongprom A., Khemakorn P., Eiamsa-ard M., Supongpan M., 2003, Status of demersal fishery resources in the Gulf of Thailand. In: Silvestre G., Garces L., Stobutzki I., Ahmed M., ValmonteSantos R.A., Luna C., Lachica-Alino L., Munro P., Christensen V., Pauly D. (eds.). Assessment, management and future directions for coastal fisheries in Asian countries. WorldFish Center Conference Proceedings 67. Penang, World Fish Center, pp. 137-152.

Krajangdara T., Puntuleng P., Chalee P., Hussadee P., 2007, Reproductive biology of short mackerel Rastrelliger brachysoma (Bleeker, 1851) and Indian mackerel R. kanagurta (Cuvier, 1816) in Thai waters. Technical Paper no. 19/2007, Bangkok, Marine Fisheries Research and Development Bureau (MFRDB), DOF.

Nasuchon N., Rotjanaratana T., 2000, Reproductive biology of goldstripe sardinella Sardinella gibbosa (Bleeker, 1849) in conservation area Prachuap Khiri Khan, Chumphon and Surat Thani province. Technical Paper no. 10/2000, Bangkok, MFD, DOF.

Noopetch L., 1983, Species composition of pelagic fished caught by luring purse seine in the Gulf of Thailand during 1975-1976. Technical Paper no. 39, Bangkok, MFD, DOF.

Noopetch L., 1984, Length frequency distribution, and age and growth determination of yellow stripe trevally Caranx leptolepis caught in the Gulf of Thailand. Technical Paper no. 47. Bangkok, MFD, DOF.

Noopetch L., 1987, Species status fisheries of luring purse seine in the Gulf of Thailand in 1986. Technical Paper no. 6, Bangkok, MFD, DOF.

Nootmorn P., 1989, A study on the population dynamics of the round scad (Decapterus maruadsi Temminck \& Schlegel, 1842) in the Gulf of Thailand. Master thesis (Fisheries Science), Bangkok, Kasetsart University.

Noranarttragoon P., 2007, An evaluation on economic loss from luring purse seine fishery in the Gulf of Thailand. Kasetsart J. (Nat. Sci.). 41, 141-148.

Pauly D., Christensen V., Froese R., Palomares M.L., 2000, Fishing down aquatic food webs. Am. Sci. 88, 46-51.

Pauly D., Palomares M.L., Froese R., Sa-a P., Vakily M., Preikshot D., Wallace S., 2001, Fishing down Canadian aquatic food web. Can. J. Fish. Aquat. Sci. 58, 51-62.

Phuttharaksa K., Nasuchon N., Kongchai T., Pinputtasin J., 2008, Reproductive biology of bigeye scad (Selar crumenophthalmus 
(Bloch, 173)) in the Gulf of Thailand. Technical Paper no. 16/2008, Bangkok, MFRDB, DOF.

Piet G.J., van Overzee H.M.J., Pastoors M.A., 2010, The necessity for response indicators in fisheries management. ICES J. Mar. Sci. 67, 559-566.

Pomeroy R., John P., Richard P., Tammy C., Emmanuel G., Cliff M., Elizabeth H., Michael P., Ayut N., Somsak B., Nguyen T.H., 2007. Fish wars: conflict and collaboration in fisheries management in Southeast Asia. Mar. Policy 3, 645-656.

Premkit W., Dowreung A., Sereerak K., 2004, Biological aspects of one finlet scad (Atule mate) in the upper Gulf of Thailand. Technical Paper no. 1/2004, Bangkok, MFRDB, DOF.

Raakjær J., Son D.M., Stæhr K.J., Hovgård H., Thuy N.T.D., Ellegaard K., Riget F., Thi D.V., Hai P.G., 2007, Adaptive fisheries management in Vietnam: The use of indicators and the introduction of a multi-disciplinary Marine Fisheries Specialist Team to support implementation. Mar. Policy 31, 143-152.

Reuben S., Kasim H.M., Sivakami S., Radhakrishnan P.N., Kurup K.N., Sivadas M., Noble A., Nair K.V.S., Raje S.G., 1992, Fishery, biology and stock assessment of carangid resources from the Indian Seas. Indian J. Fish. 39, 195-234.

Saikliang P., 1997, Fishery resources and the state of exploitation of some economic fish species in the South China Sea area Case study: Malaysia and Thai waters. In: Fishery resources and state of stocks exploitation in the waters of the Gulf of Thailand, east coast of Peninsular Malaysia and Andaman Sea, Bangkok, SEAFDEC. pp. 59-90.

Saikliang P., 2003, Status of sardine resources and fisheries in the Gulf of Thailand. Technical Paper no. 13/2003, Bangkok, MFRDB, DOF.

Stobutzki I.C., Silvestre G.T., Garces L.R., 2006a, Key issues in coastal fisheries in South and Southeast Asia, outcomes of a regional initiative. Fish. Res. 78, 109-118.

Stobutzki I.C., Silvestre G.T., Talib A.A., Krongprom A., Supongpan M., Khemakorn P., Armada N., Garces L.R., 2006b, Decline of demersal coastal fisheries resources in three developing Asian countries. Fish. Res. 78, 130-142.

Sumaila U.R., 2010, A cautionary note on individual tranferable quotas. Ecol Soc. 15, 36 http://www.ecologyandsociety.org/vol15/ iss $3 / \operatorname{art} 36 /$

Supongpan M., 2001, Possible indicators for improved management of marine capture fisheries in ASEAN countries. In: Proceedings of the regional technical consultation on indicators for sustainable fisheries management in ASEAN region. 2-5 May 2001, Haiphong, Ministry of Fisheries, Vietnam, pp. 122-135.

Supongpan S., Saikliang P., 1987, Fisheries status of tuna purse seiners (using sonar) in the Gulf of Thailand in 1983. Technical paper no. 3/1987, Bangkok, MFD, DOF. 